\title{
Stable Isotopes Studies in the Urucu Oil Province, Amazon Region, Brazil
}

\author{
Eliene Lopes de Souza', Paulo Galvão²*, Roseli de Almeida1, Cleane Pinheiro³, \\ Marcus Baessa ${ }^{4}$, Marcio Cabral ${ }^{1}$ \\ ${ }^{1}$ Institute of Geosciences, Federal University of Pará (UFPA), Belém, Brazil \\ ${ }^{2}$ Institute of Geosciences, University of São Paulo, São Paulo, Brazil \\ ${ }^{3}$ Institute of Environment and Spatial Planning of the State of Amapá (IMAP), Macapá, Brazil \\ ${ }^{4}$ Leopoldo Américo Miguez de Mello Center for Research and Development (CENPES), Rio de Janeiro, Brazil \\ Email: ${ }^{\text {hidropaulo@gmail.com }}$
}

Received 18 January 2015; accepted 2 February 2015; published 6 February 2015

Copyright (C) 2015 by authors and Scientific Research Publishing Inc.

This work is licensed under the Creative Commons Attribution International License (CC BY).

http://creativecommons.org/licenses/by/4.0/

cc) (i) Open Access

\begin{abstract}
The study area is the Urucu Oil Province, Municipality of Coari, State of Amazonas, Brazil. This research represents a contribution to the hydrogeological knowledge in the northern region of Brazil, particularly in the central part of the Amazon rainforest, where researches on isotopic are still incipient. The primary goal was to determine, by stable isotopes ${ }^{18} \mathrm{O}$ and ${ }^{2} \mathrm{H}$ measurements, interrelationships between surface water and groundwater, in order to understand the origin and mechanisms of groundwater recharge and discharge. For this, samples of rainwater, superficial water and groundwater were collected between June 2008 and May 2009 for stable isotopic analyzes. This understanding is important in cases of eventual contaminations of the area, which could degrade the water resources. The results show that the superficial waters are typically light waters and have meteoric origin, and the groundwater recharge is by direct rainfall infiltration with primary evaporation before reaching the groundwater table in the Içá-Solimões Aquifer System. The isotopic signatures similarities between groundwater and superficial waters indicate both waters' contributions in the streams and, therefore, in the Urucu river.
\end{abstract}

\section{Keywords}

Stable Isotopes, Hydrogeology, Water Management, Surface Water, Groundwater

\section{Introduction}

The use of stable isotopes in hydrogeology started in the 50s, with the pioneering works of Urey et al. and Eps-

*Corresponding author.

How to cite this paper: de Souza, E.L., Galvão, P., de Almeida, R., Pinheiro, C., Baessa, M. and Cabral, M. (2015) Stable Isotopes Studies in the Urucu Oil Province, Amazon Region, Brazil. Journal of Water Resource and Protection, 7, 131-142. 
tein and Mayeda, in the reference [1]. Through time, these studies have shown to be an effective way for investigating the complex hydrologic system on a range of spatial and temporal scales, providing quantitative information about surface-ground water interactions.

Physically, the stable isotopes are atoms that take the same position in the table of elements, but have a different number of neutrons and, therefore, mass. The most relevant isotopes for atmospheric and hydrologic sciences are ${ }^{18} \mathrm{O}$ for oxygen (corresponding to the most abundant isotope ${ }^{16} \mathrm{O}$ ), and ${ }^{2} \mathrm{H}$ (or Deuterium, D) for hydrogen (corresponding to the most abundant isotope ${ }^{1} \mathrm{H}$ ) [2] [3]. These isotopes, during evaporation and condensation phases, become enriched in one phase and depleted in the other. This separation of isotopes is named isotopic fractionation [3], and quantifying these processes is possible by calculating the large variability of their isotopic ratios $\left({ }^{2} \mathrm{H} / \mathrm{H}\right.$ and $\left.{ }^{18} \mathrm{O} /{ }^{16} \mathrm{O}\right)$.

Measurements of stable isotopes also require a common standard. For atmospheric applications, the usual standard is the Vienna Standard Mean Ocean Water (V-SMOW), published and distributed regularly by the International Atomic Energy Agency (IAEA). The delta $(\delta)$ notation is used to quantify stable isotope as relative ratios and the isotopes values are reported in per mil (\%) to make it easy to compare significant results. Different results from the standard V-SMOW provide information about recharge and discharge processes; flow, mixing and interconnections among aquifers; evaporation; marine influence; and the sources and mechanism of pollution [1].

Reference [4] observed that the $\delta^{18} \mathrm{O}$ and $\delta^{2} \mathrm{H}$ values of precipitation that have not been evaporated are linearly related by the equation $\delta^{2} \mathrm{H}=8 \delta^{18} \mathrm{O}+10$. This equation, known as the Global Meteoric Water Line (GMWL), is based on precipitation data from locations around the globe, and has an $\mathrm{r}^{2}>0.95$. This high correlation coefficient reflects the fact that the oxygen and hydrogen stable isotopes in water molecules are intimately associated. The slope and intercept of any Local Meteoric Water Line (LMWL), which is the line derived from precipitation collected from a single site or set of "local" sites, can be significantly different from the GMWL.

Many researchers use oxygen and hydrogen isotopes for investigating different situations, such as storm hydrographs [5]-[8], surface-ground water interactions [9]-[11], and integration of upstream waters [12] [13]. These studies demonstrated the usefulness and applicability of stable isotopes as conservative tracers for hydrogeological studies. In Brazil, the first hydrogeological studies using stable isotopes started in the late 60s and early 70s in the Northeast and Southeast regions, and in the Amazon region [14]. In the Northeast region, the studies were developed to know the origin and mechanisms of groundwater recharge, salinization, transit time and age of waters [15]-[24]. In the Southeast region, studies were initiated in the 80s, especially in the state of São Paulo, where the use of groundwater supply stimulated the isotopic characterization in large aquifers, such as the Guarani Aquifer [25]-[27], or the impact of the sealing surface in aquifer recharging [28]. Studies developed in the Amazon region had the objective of calculating the stream flow of the Negro and Solimões rivers and estimating their contributions to the Amazon River [29]. In parallel, the characterization of the isotopic composition of precipitation was analyzed to develop the local meteoric water line. In this context, several isotopic studies were developed [30]-[34], concluding that the rain is conditioned in part by processes of evapotranspiration [32] [33] [35] [36]. Other studies about hydrological cycle and surface-ground water interactions were carried out [30] [37]-[39].

In regards to this paper, the primary goal was to determine, by stable isotopes ${ }^{18} \mathrm{O}$ and ${ }^{2} \mathrm{H}$ measurements, the interrelationships between surface water and groundwater in the Urucu Oil Province, in the Municipality of Coari, state of Amazonas, Brazil, in order to understand the origin and mechanisms of groundwater recharge and discharge. This understanding is important in cases of eventual contaminations, which could degrade the water resources. For this, samples of rainwater (to perform the Local Meteoric Water Line for Urucu-UMWL), superficial water, and groundwater were collected between June 2008 and May 2009 for stable isotopic analyzes.

\section{Site Description}

The study area is the Geologist Pedro Leopoldo de Moura Operational Base (BOGPM) [BOGPM-Base Operacional Geólogo Pedro Leopoldo de Moura], located in the Urucu Oil Province, Municipality of Coari, state of Amazonas, Brazil, $650 \mathrm{~km}$ southwest from Manaus, the state capital (Figure 1). This province is known by the greatness of its enterprise, becoming a true enclave in the middle of the Amazon rainforest, which has a daily production of about 100 thousand barrels of oil equivalent (BOE) and 10.36 thousand cubic meters of natural gas per day [40] [41]. 


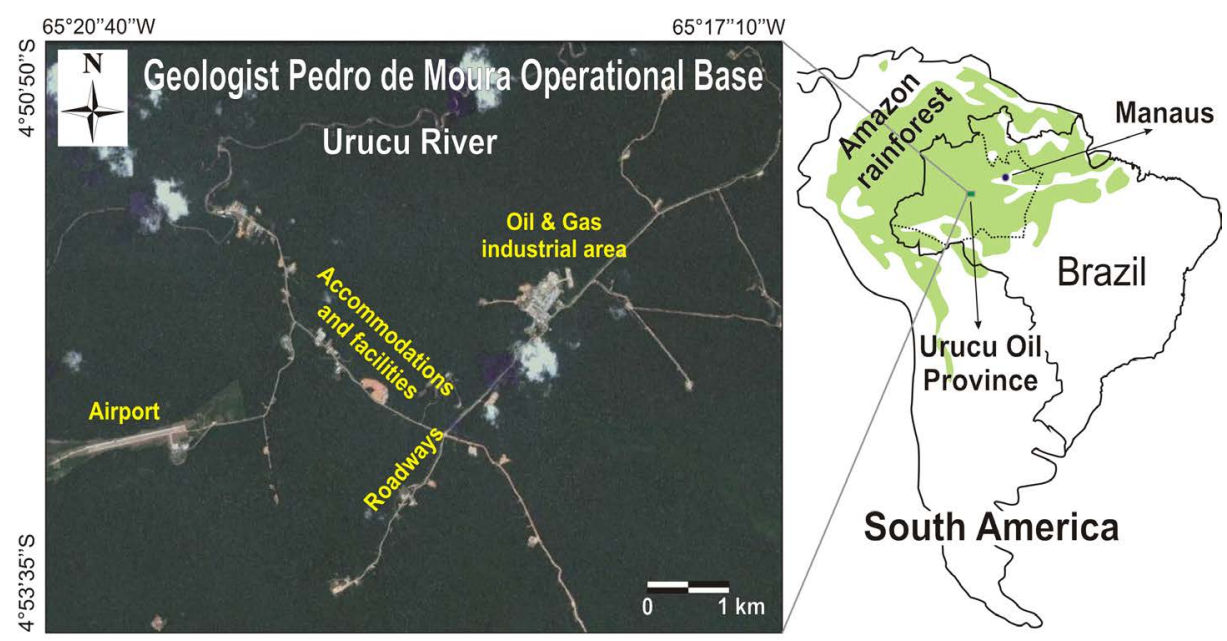

Figure 1. Location map of the study area (modified from Google Earth).

This tropical region is characterized by high precipitation (ranging between 2250 and 2750 mm/year), in which the winter season usually begins in October, with the highest levels of precipitation in January, February and March. The annual mean temperature is $25^{\circ} \mathrm{C}$, with a mean seasonal fluctuation of about $1^{\circ} \mathrm{C}$. The relative humidity is quite high, between $85 \%$ - 90\% [41]. Topographically, the region does not have much variation in the elevation, varying between 70 and 90 meters above sea level [41].

The study area is located in the Urucu River Watershed. The main river is the Urucu River, a tributary of the Solimões River, which flows into the Coari Lake. In the BOGPM, there are some creeks, such as Tartaruga and Onça creeks, that flow into the Urucu River [41].

Geologically, the study area is located in the Solimões Paleozoic sedimentary basin [42] [43]. There were five sedimentary depositional sequences on this basin: Ordovician, Silurian-Devonian, Devonian-Carboniferous, Carboniferous-Permian, Cretaceous, and Tertiary-Quaternary [44]. The study area is in the sediments from Cretaceous and Tertiary-Quaternary sequences, represented by the following formations, from bottom to top: 1) Alter do Chão Formation: coarse grained friable sandstones [45] [46]. The age of the upper part of this formation is estimated to be Neo-Cretaceous, by correlation with the Amazonas Basin [42]. The depositional environment is continental, with plain facies and alluvial fans; 2) Solimões Formation: laminated mudstones, lignites layers, and fine to coarse grained sandstones [42]. This formation is estimated to be Miocene/Pliocene, suggesting a meandering fluvial depositional environment and lakes formed by abandoned channels [47]; and 3) Içá Formation: fine to medium grained sandstones and siltstones, with occasional occurrences of conglomerates [48].

Hydrogeologically, the Solimões and Içá Formations, which can have 100 - $120 \mathrm{~m}$ thickness, constitute a good water reservoir. The intercalations between these sandstones with clays lenses allow, in some areas, an individualization of two aquifers, hydraulically connected, constituting the semi-confined Içá-Solimões Aquifer System. Right below, the Solimões Aquiclude is constituted by argillite with 150 - 180 m thickness, having the lower contact with the Alter do Chão Aquifer, established by coarse sandstones, good porosity and permeability [49]. The geometry of the Içá-Solimões Aquifer System has a convex shape on the top and a thickness between 50 and $100 \mathrm{~m}$. The hydrodynamic parameters estimated were: transmissivity: $3 \times 10^{-3} \mathrm{~m}^{2} / \mathrm{s}$; storativity: $5 \times 10^{-4}$; and hydraulic conductivity: $1 \times 10^{-4} \mathrm{~m} / \mathrm{s}$. The potentiometric surface has general flow direction to NNW-SSE, converging to the Urucu River. A considerable cone of depression in the center of the BOGPM is common, due changes in groundwater flow induced by high rate pumping wells [49].

\section{Materials and Methods}

Water samples were collected during June 2008 and May 2009 in 5 supply wells, rainwater, and 2 surface water points. The location of the sampling points is shown in the Figure 2, while the results can be seen in the Table 1. The main concern with these samples was to avoid the post-sampling fractionation. For this, pre-cleaned polypropylene vials $(30 \mathrm{ml})$ were used. These vials were completely filled with samples, avoiding air bubbles inside, and stored in coolers, maintaining the temperature, according to the reference [27]. All these samples were analyzed 


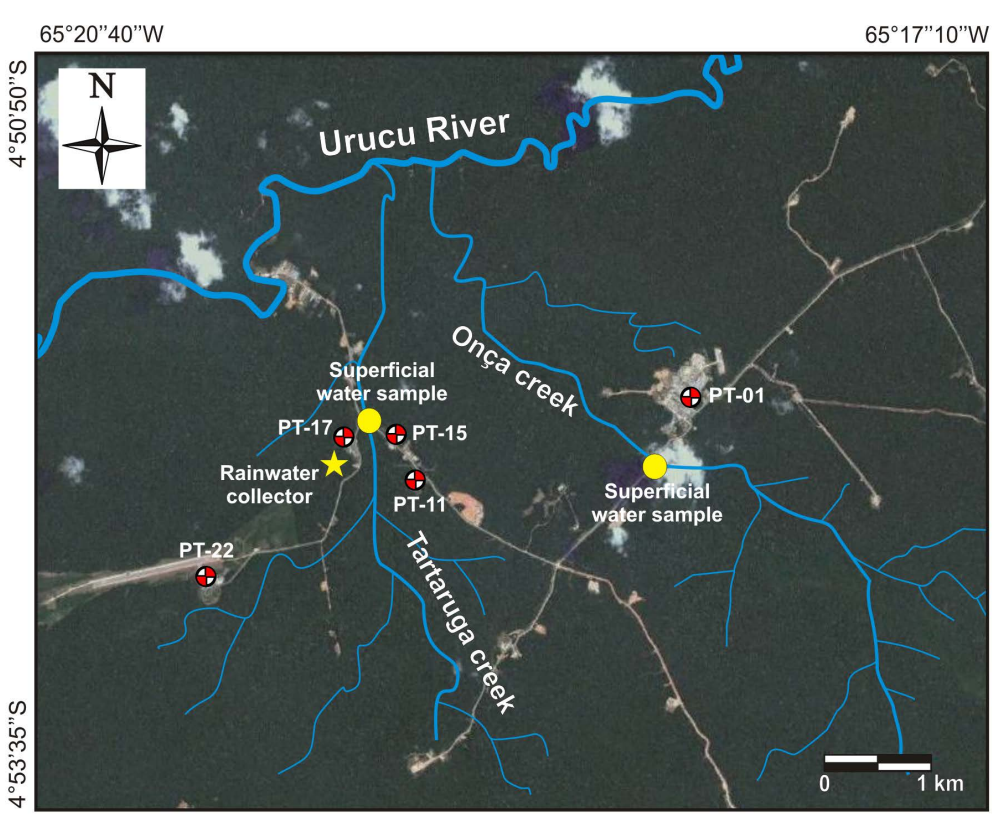

Figure 2. Location map of sampling points, showing locations of supply wells, rainwater collector and surface water at Onça creek and Tartaruga creek (modified from Google Earth).

Table 1. Monthly isotopic concentrations of rainwater, surface water (Onça and Tartaruga creeks) and groundwater samples (supply wells PT-01, 11, 15, 17 and 22), from June 2008 to May 2009.

\begin{tabular}{|c|c|c|c|c|c|c|c|c|c|c|c|c|c|c|}
\hline \multirow{2}{*}{ Water type } & \multirow{2}{*}{$\begin{array}{l}\text { Sample } \\
\text { location }\end{array}$} & \multirow{2}{*}{$\begin{array}{c}\text { Stable } \\
\text { isotopes } \\
\text { (\%o) }\end{array}$} & \multicolumn{7}{|c|}{2008} & \multicolumn{5}{|c|}{2009} \\
\hline & & & Jun & Jul & Aug & Sep & Oct & Nov & Dec & Jan & Feb & Mar & Apr & May \\
\hline \multirow{2}{*}{ Rain } & \multirow[t]{2}{*}{ BOGPM } & $\delta^{18} \mathrm{O}$ & -6.7 & -3.5 & -2.2 & 1.7 & - & 0.3 & -8.5 & - & -9.4 & -11.9 & -13.8 & -9.6 \\
\hline & & $\delta^{2} \mathrm{H}$ & -33.8 & -12.6 & 0.1 & 19.8 & - & 13.4 & -52.8 & - & -57.4 & -80.2 & -94.2 & -63.4 \\
\hline \multirow{4}{*}{$\begin{array}{l}\text { Superficial } \\
\text { water }\end{array}$} & \multirow{2}{*}{$\begin{array}{l}\text { Tartaruga } \\
\text { creek }\end{array}$} & $\delta^{18} \mathrm{O}$ & -7.0 & -4.9 & -3.2 & -4.2 & - & -3.9 & -5.6 & - & -6.4 & -7.8 & -8.9 & -6.9 \\
\hline & & $\delta^{2} \mathrm{H}$ & -32.0 & -28.1 & -15.0 & -22.8 & - & -18.7 & -28.9 & - & -37.1 & -50.8 & -59.2 & -43.4 \\
\hline & \multirow{2}{*}{ Onça creek } & $\delta^{18} \mathrm{O}$ & -6.4 & -5.5 & -4.6 & -4.4 & - & -4.4 & -5.3 & - & -6.1 & -8.6 & -9.9 & -6.9 \\
\hline & & $\delta^{2} \mathrm{H}$ & -31.9 & -28.9 & -20.9 & -22.2 & - & -21.1 & -28.6 & - & -36.7 & -56.5 & -64.3 & -40.8 \\
\hline \multirow{10}{*}{ Grounwater } & \multirow{2}{*}{$\begin{array}{l}\text { PT-01 } \\
\left(91 \mathrm{~m}^{*}\right)\end{array}$} & $\delta^{18} \mathrm{O}$ & - & -5.8 & -5.5 & -5.5 & - & - & -5.5 & - & -5.7 & -5.6 & -5.9 & -5.9 \\
\hline & & $\delta^{2} \mathrm{H}$ & - & -32.9 & -31.7 & -31.5 & - & - & -31.1 & - & -31.1 & -31.4 & -33.3 & -34.8 \\
\hline & \multirow{2}{*}{$\begin{array}{c}\text { PT-11 } \\
\left(110 \mathrm{~m}^{*}\right)\end{array}$} & $\delta^{18} \mathrm{O}$ & -5.9 & -5.6 & -5.5 & -5.5 & - & -5.9 & -5.8 & - & -4.1 & -4.1 & -4.9 & -4.9 \\
\hline & & $\delta^{2} \mathrm{H}$ & -28.8 & -30.6 & -30.5 & -30.1 & - & -32.0 & -32.5 & - & -24.1 & -24.1 & -27.6 & -27.3 \\
\hline & \multirow{2}{*}{$\begin{array}{c}\text { PT-15 } \\
\left(120 \mathrm{~m}^{*}\right)\end{array}$} & $\delta^{18} \mathrm{O}$ & -5.6 & -4.9 & -5.1 & -4.7 & - & -5.1 & -4.7 & - & -5.1 & -4.8 & -5.5 & -5.8 \\
\hline & & $\delta^{2} \mathrm{H}$ & -32.3 & -28.7 & -30.9 & -27.3 & - & -28.0 & -28.1 & - & -31.5 & -30.0 & -29.4 & -32.9 \\
\hline & \multirow{2}{*}{$\begin{array}{l}\text { PT-17 } \\
\left(40 \mathrm{~m}^{*}\right)\end{array}$} & $\delta^{18} \mathrm{O}$ & -5.5 & -5.2 & -5.1 & -4.5 & - & -4.3 & -5.7 & - & -5.8 & -5.8 & -6.1 & -6.1 \\
\hline & & $\delta^{2} \mathrm{H}$ & -32.0 & -30.4 & -29.4 & -28.0 & - & -28.5 & -32.2 & - & -31.4 & -32.6 & -32.6 & -32.6 \\
\hline & \multirow{2}{*}{$\begin{array}{l}\text { PT-22 } \\
\left(40 \mathrm{~m}^{*}\right)\end{array}$} & $\delta^{18} \mathrm{O}$ & -4.8 & -4.5 & -5.1 & -4.9 & - & -5.2 & -5.3 & - & - & -4.9 & - & -4.6 \\
\hline & & $\delta^{2} \mathrm{H}$ & -26.2 & -25.1 & -26.6 & -26.0 & - & -27.3 & -27.3 & - & - & -27.4 & - & -26.2 \\
\hline
\end{tabular}

*Depth of the well screen section; - = No sample due technical problem or well maintenance. 
for ${ }^{18} \mathrm{O}$ and ${ }^{2} \mathrm{H}$ at the Center for Nuclear Energy in Agriculture, University of São Paulo (CENA-USP), City of Piracicaba, São Paulo.

Cumulative monthly rain isotope samples were collected to perform the Urucu Meteoric Water Line (UMWL) for a hydrological year. For this, two polypropylene bottles $(5 \mathrm{~L})$ interconnected to each other were used and placed in a cooler to keep the temperature and prevent sunlight penetration. The first bottle had a funnel, to catch the rainwater. When the first bottle was completely filled, the rainwater began to flow into the second one through the connection between them. A silicone hose was also attached on the bottle to balance the pressure and prevent exchanges with atmospheric air [28] (Figure 3). This method followed the GNIP (Global Network of Isotopes in Precipitation) instruction, where evaporation and loss of lighter isotopes are negligible [50].

The surface water samples were collected in two creeks: the Onça creek and the Tartaruga creek (Figure 2). For this, samples were taken from a bridge, sampling waters from the center of them.

The groundwater samples were taken in 5 wells (PT-01, 11, 15, 17 and 22) used to supply the Oil Province of Urucu (Figure 2), giving preference to those who had only one well screen section, except the PT-01, which had some well screen sections (the depth of screen section of each well can be seen in the Table 1). There was no sampling in the months that these wells were in maintenance, due to technical problems (October 2008 and January 2009). The groundwater samples were taken after removing several well volumes of water, using pumps installed in these wells. This was done to purge the aquifer of stagnant water and to acquire fresh aquifer samples for analysis.

\section{Result and Discussion}

\subsection{Rainwater}

In the Urucu Oil Province, the rainy season occurs from December to May, with mean rainfall of $1521 \mathrm{~mm}$, corresponding to $65.3 \%$ of annual precipitation. The period with less precipitation occurs from June to September, with $806 \mathrm{~mm}$, equivalent to $34.7 \%$ of the annual total. The average annual temperature is $25.8^{\circ} \mathrm{C}$, which June has the lowest value $\left(25.3^{\circ} \mathrm{C}\right)$, and September the highest $\left(26.3^{\circ} \mathrm{C}\right)$. The annual variation is only $1^{\circ} \mathrm{C}$, which is common in tropical regions, where changes in air temperature are minimal [51] (Figure 4). A comparison

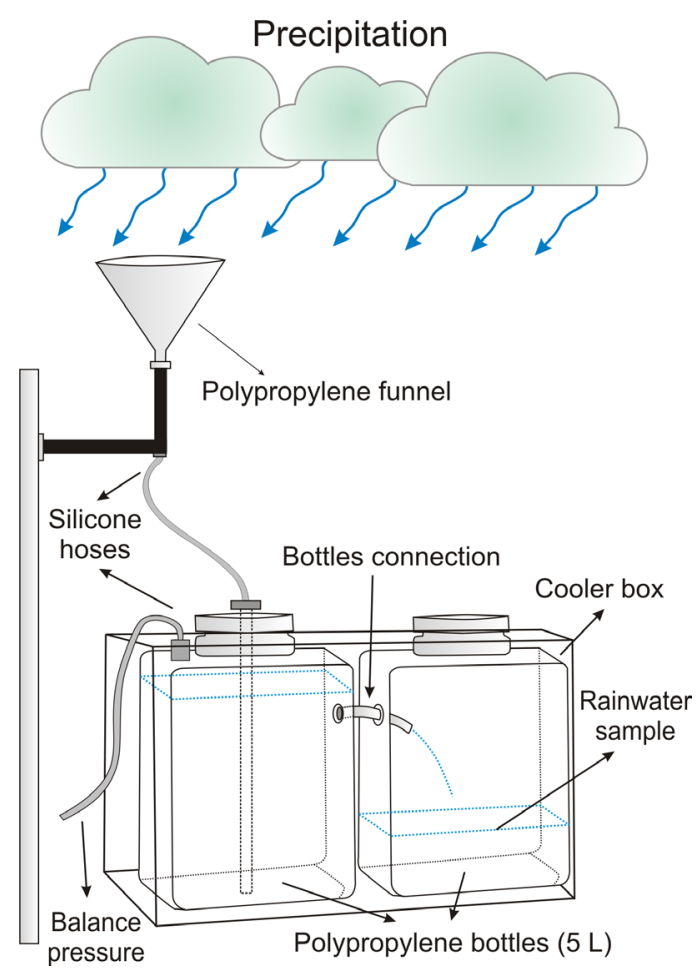

Figure 3. Rainwater collector to perform the local meteoric water line. 


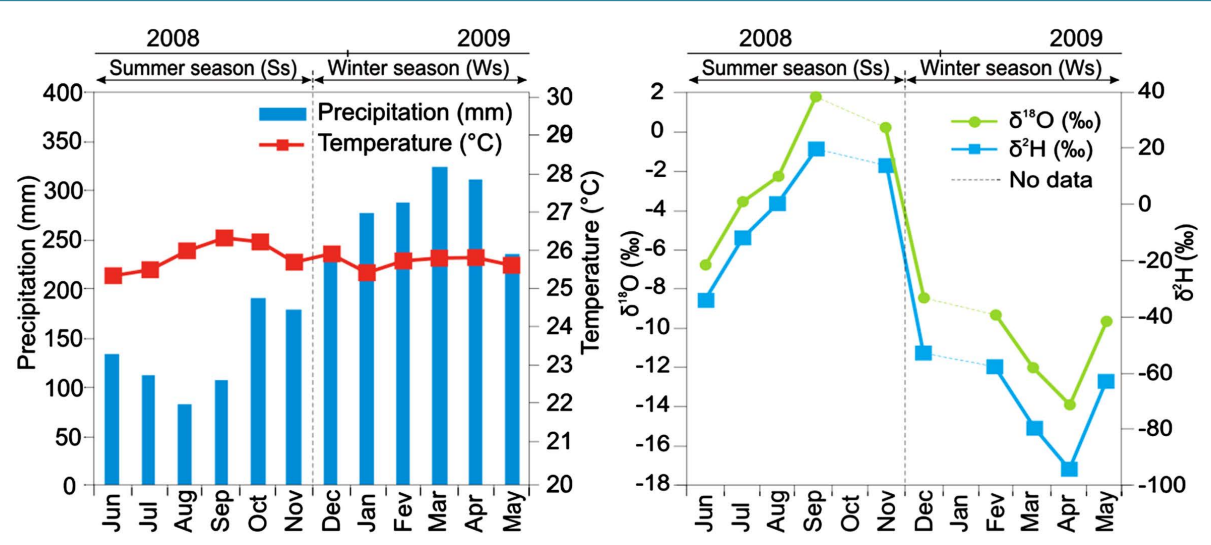

Figure 4. Comparison between climatic data and isotopic concentrations of rainwater, showing an inverse relationship between precipitation and isotopic concentrations.

between monthly rainfall and relative deviations $\left(\delta^{2} \mathrm{H}\right.$ and $\left.\delta^{18} \mathrm{O}\right)$ observed that in the month such as March 2009 $\left(\delta^{2} \mathrm{H}=-80.2 \%\right.$; $\left.\delta^{18} \mathrm{O}=-11.9 \%\right)$ and April $2009\left(\delta^{2} \mathrm{H}=-94.2 \%\right.$; $\delta^{18} \mathrm{O}=-13.8 \%$ ) showed the minor deviations for both ${ }^{2} \mathrm{H}$ and ${ }^{18} \mathrm{O}$ (Figure 4 and Table 1). These values, indicative of water with low concentrations of heavy isotopes (light water), coincide with the months of greatest amount of rainfall. Otherwise, the highest deviation, which indicate heavier water, was recorded in September $2008\left(\delta^{2} \mathrm{H}=19.8 \%\right.$; $\delta^{18} \mathrm{O}=1.7 \%$ ) and November $2008\left(\delta^{2} \mathrm{H}=13.4 \%\right.$; $\delta^{18} \mathrm{O}=0.3 \%$ ) (Figure 4 and Table 1). This relationship between isotopic composition of rainwater samples and precipitation was expected because there is usually a depletion of heavy isotopes (water becoming lighter) when the rainfall increase [30] [52].

\subsection{Superficial Water}

The annual isotopic variation of superficial water relative to the Onça creek ranged between $\delta^{2} \mathrm{H}=-20.90 \%$ to $-64.30 \%$ and $\delta^{18} \mathrm{O}=-4.38 \%$ o to $-9.90 \%$, while in the Tartaruga creek it ranged between $\delta^{2} \mathrm{H}=-15.00 \%$ o to $-59.20 \%$ and $\delta^{18} \mathrm{O}=-3.21 \%$ to $-8.97 \%$ (Figure 5 and Table 1 ).

The superficial water samples showed the same inverse relationship between precipitation and isotopic concentrations seen in Figure 4 (Figure 5). In the winter period, there was depletion in the concentration of $\delta^{2} \mathrm{H}$ and $\delta^{18} \mathrm{O}$, while in the summer period there was an isotopic enrichment. This can be interpreted by the surface water evaporation, losing lighter isotopes, or reflecting the type of rainwater that is contributing in the surface water.

\subsection{Groundwater}

The annual isotopic variation of groundwater samples ranged between: PT- $01\left(\delta^{2} \mathrm{H}=-31.10 \%\right.$ to $-34.80 \%$ and $\delta^{18} \mathrm{O}=-5.49 \%$ to $-5.93 \%$ ); PT-11 ( $\delta^{2} \mathrm{H}=-24.10 \%$ to $-32.50 \%$ and $\delta^{18} \mathrm{O}=-4.15 \%$ o to $-5.93 \%$ \%); $\mathrm{PT}-15\left(\delta^{2} \mathrm{H}=\right.$ $-27.30 \%$ to $-32.90 \%$ and $\delta^{18} \mathrm{O}=-4.76 \mathrm{v}$ to $-5.79 \%$ ); PT-17 ( $\delta^{2} \mathrm{H}=-28.20 \%$ to $-32.60 \%$ and $\delta^{18} \mathrm{O}=-4.33 \%$ o to $-6.16 \%$ ); and PT-22 ( $\delta^{2} \mathrm{H}=-25.10 \%$ o to $-27.40 \%$ and $\delta^{18} \mathrm{O}=-4.55 \%$ to $-5.26 \%$ ) (Figure 6 and Table 1).

In general, the groundwater samples collected both in the deep and shallower zones of the Içá-Solimões Aquifer System did not show a significant pattern related with periods of high or low precipitation, as were noted in rainwater and superficial water samples. However, both samples from shallower zones (PT-17-40 m; PT-22-40 m) and deeper zones of the aquifer (PT-01-91 m; PT-15-120 m) showed a small isotopic enrichment in the summer period, reducing concentrations of $\delta^{2} \mathrm{H}$ and $\delta^{18} \mathrm{O}$ during winter (water becoming lighter). This behavior follows the same trend seen in the rainwater and superficial water, but with a less accentuated variation. The exception was the PT-11, located in deeper zones $(110 \mathrm{~m})$, which showed an isotopic depletion in the summer and a significant enrichment in the winter.

\subsection{Relationship among Rainwater, Surface Water, and Groundwater}

The isotopic values for rainwater, which represent the Urucu Meteoric Water Line (UMWL), were compared with the Global Meteoric Water Line (GMWL), as well as the Meteoric Water Line for Marajó Island [30], 

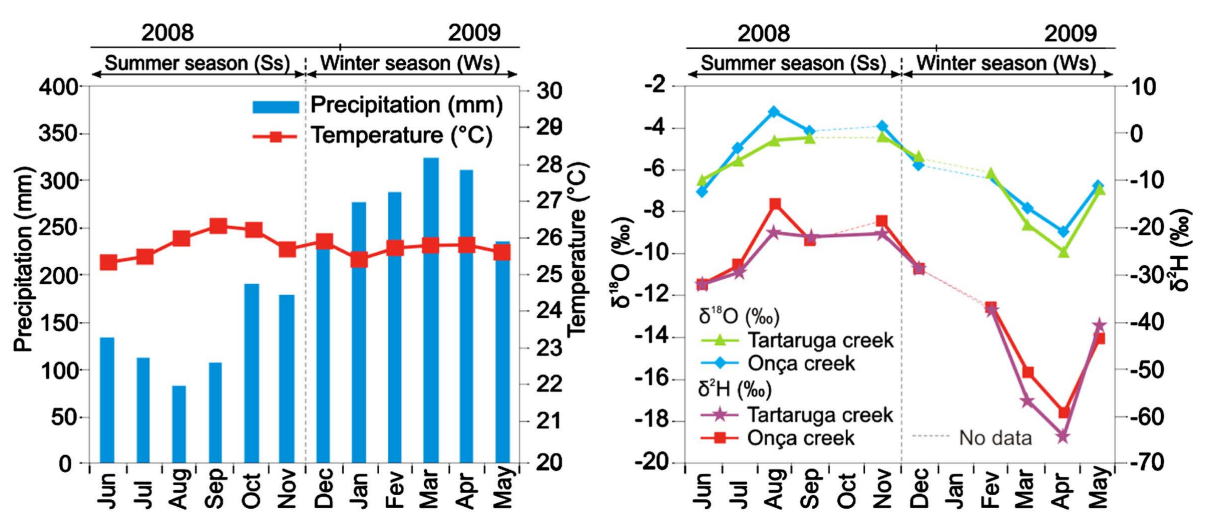

Figure 5. Annual variation of $\delta^{2} \mathrm{H}$ and of $\delta 18 \mathrm{O}$ for surface waters in the Onça and Tartatuga creeks, showing an inverse relationship between precipitation and isotopic concentrations.
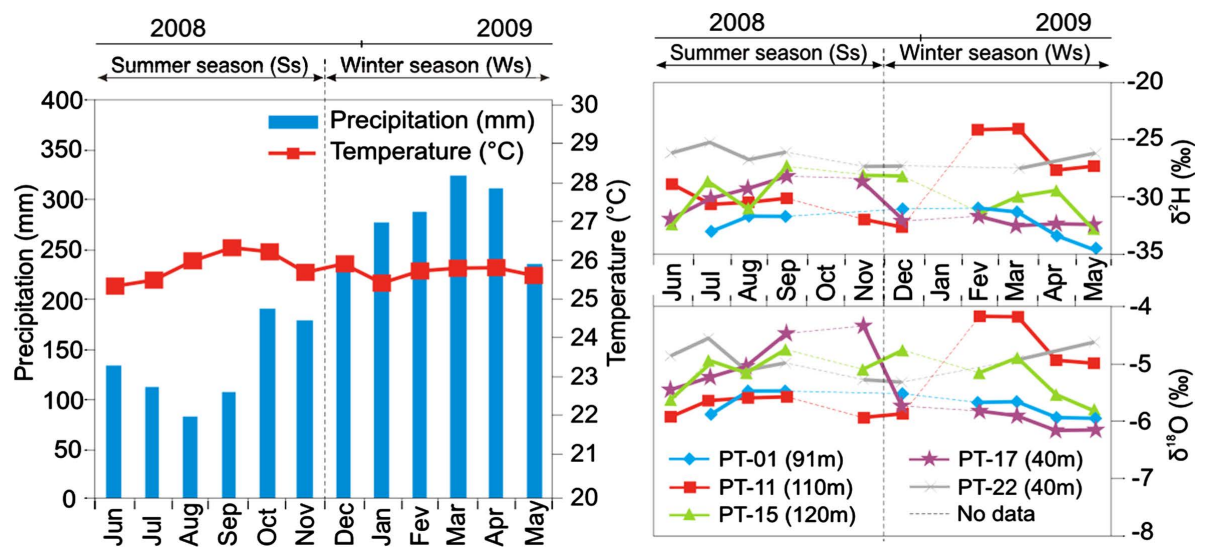

Figure 6. Annual precipitation and isotopic variation of $\delta^{2} \mathrm{H}$ and $\delta^{18} \mathrm{O}$ for groundwater samples collected both in the deep (PT-01, 11, 15) and shallower zones (PT-17 and 22).

located in the state of Pará, about $1800 \mathrm{~km}$ northwest from Urucu, which has similar climate (Figure 7). The results showed a similarity between these lines, of which the slope of the UMWL indicated a proximity to GMWL and the Meteoric Water Line for Marajó Island, close to 8. However, the UMWL was a little more negative, indicating waters slightly lighter, in comparison to the others lines, due to Urucu being further from the ocean, causing more isotopic fractionation.

The isotopic concentrations for superficial water showed that the majority of the samples are plotted between the GMWL and UMWL, suggesting a typically light waters and meteoric origin (Figure 8), which confirm rainwater contributions in the creeks.

Another comparison was made with waters from the Amazon River, collected in the Marajó Island [30]. According to this study, waters from Amazon River are typically light, due to the most of these waters originating from regions far from the ocean. The comparison showed similarities between both waters, with waters from Urucu slightly lighter than waters from Amazon River. Thus, it is possible to deduce that superficial waters from Urucu have also meteoric origin, with waters coming from regions far from the ocean. The fact that Urucu has lighter rainfall in comparison to the LMWL for Marajó Island (Figure 7) also explains lighter superficial waters, in comparison to waters from Amazon River.

The groundwater in Urucu has a different pattern in comparison with the GMWL and UMWL. The majority of the samples were plotted between these lines, with some samples on or near the lines, while others were plotted fairly tightly in the lower left. However, taking into account only the UMWL, the majority of the groundwater samples were grouped below the local line, but close (Figure 9). According to the reference [53], this situation shows the possibility of secondary fractionation processes, such as previous evaporation before infiltration or isotopic exchange within the aquifer. So, the facts that all the samples were plotted closer or on the line are likely to be recharged directly from local precipitation with little evaporation. 


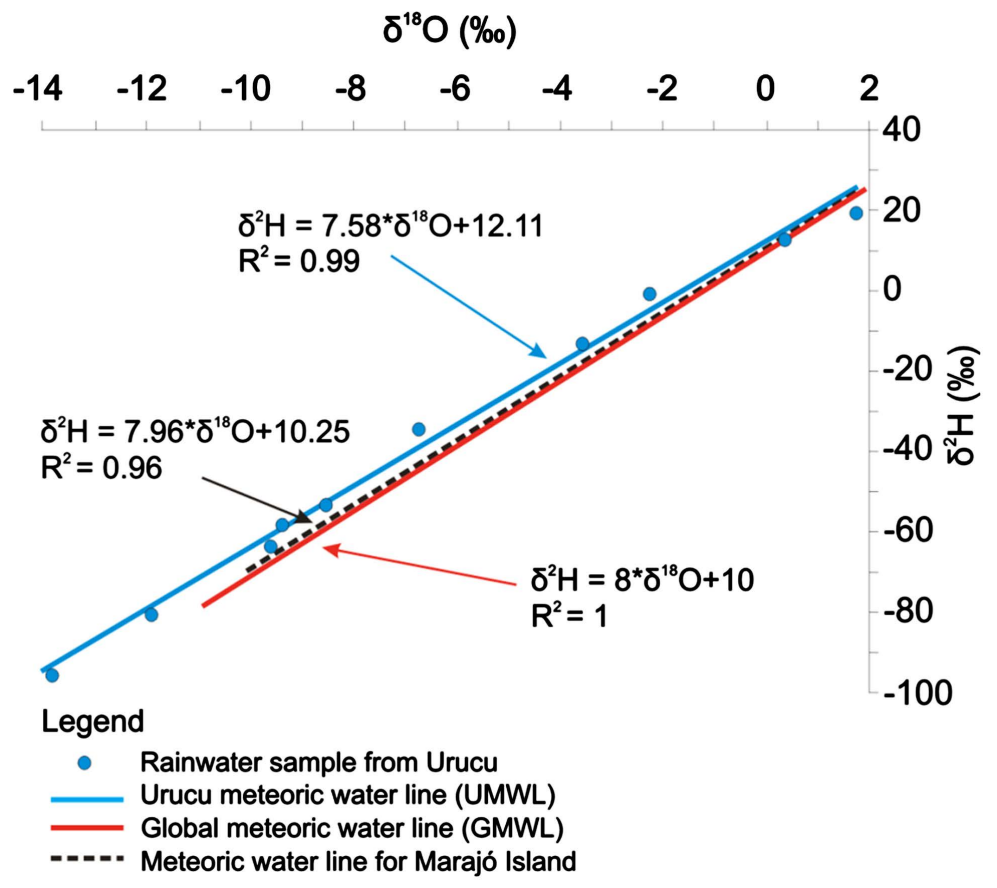

Figure 7. The Urucu Meteoric Water Line (UMWL) in comparison with the Global Meteoric Water Line (GMWL) and the Meteoric Water Line for Marajó Island (Reis et al., 1977). The results have shown a similarity between these lines, with the UMWL little more negative, indicating waters slightly lighter, in comparison to the others lines.

$$
\delta^{18} \mathrm{O}(\%)
$$

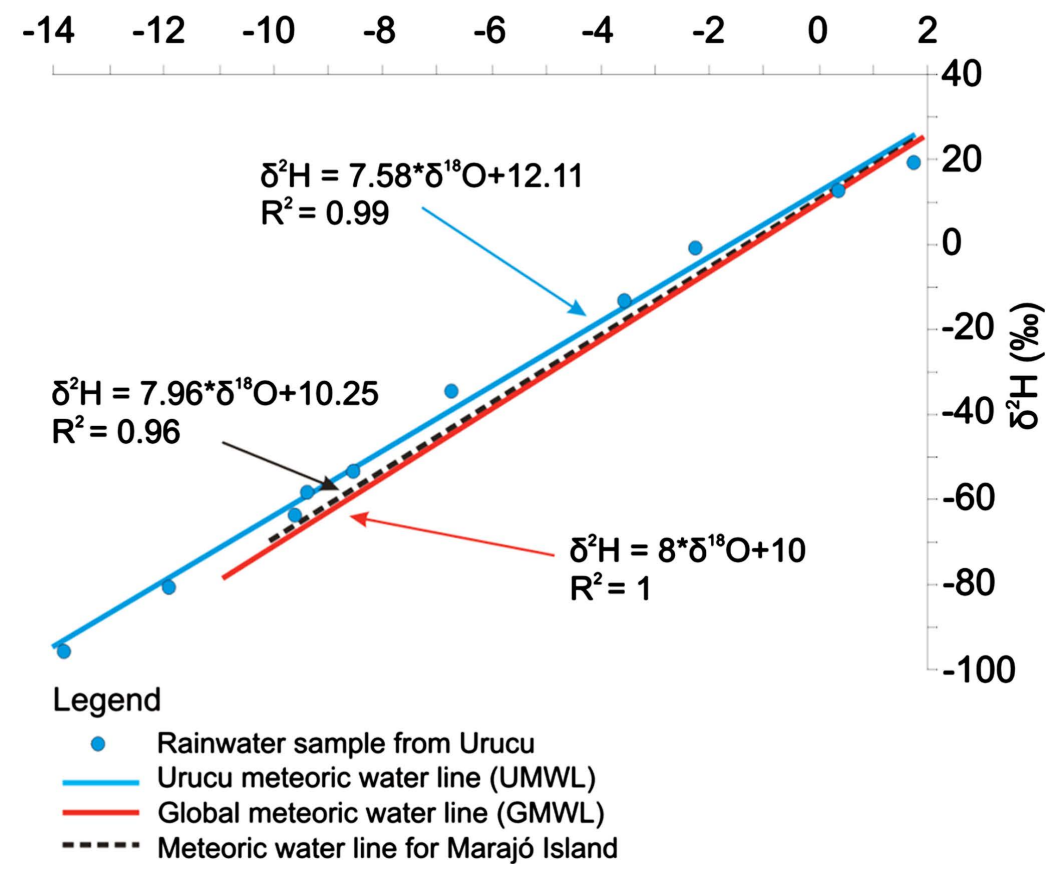

Figure 8. Comparison between isotopic concentrations of surface water from the Onça and Tartaruga creeks with the UMWL, GMWL and waters from the Amazon River, collected in the Marajó Island (Reis et al., 1977). The waters from the creeks are typically light, showing a meteoric origin. 
A comparison was made with groundwater samples collected in Marajó Island [30] and in the city of Monte Alegre [39], located in the same region (Figure 10). In the city of Monte Alegre, the samples showed similarities with the GMWL, suggesting a current meteoric origin for groundwater. In the case of Marajó Island, samples collected at a depth of $80 \mathrm{~m}$ showed heavier isotopic compositions, reflecting different water sources of the aquifer, while samples collected at $5.5 \mathrm{~m}$ depth, showed lighter isotopic compositions, similar to the meteoric waters. In Urucu, a significant isotopic variation was not observed between waters from different zones of the aquifer, as seen in Marajó Island, which means that the groundwater in Urucu probably originates from the same water source.

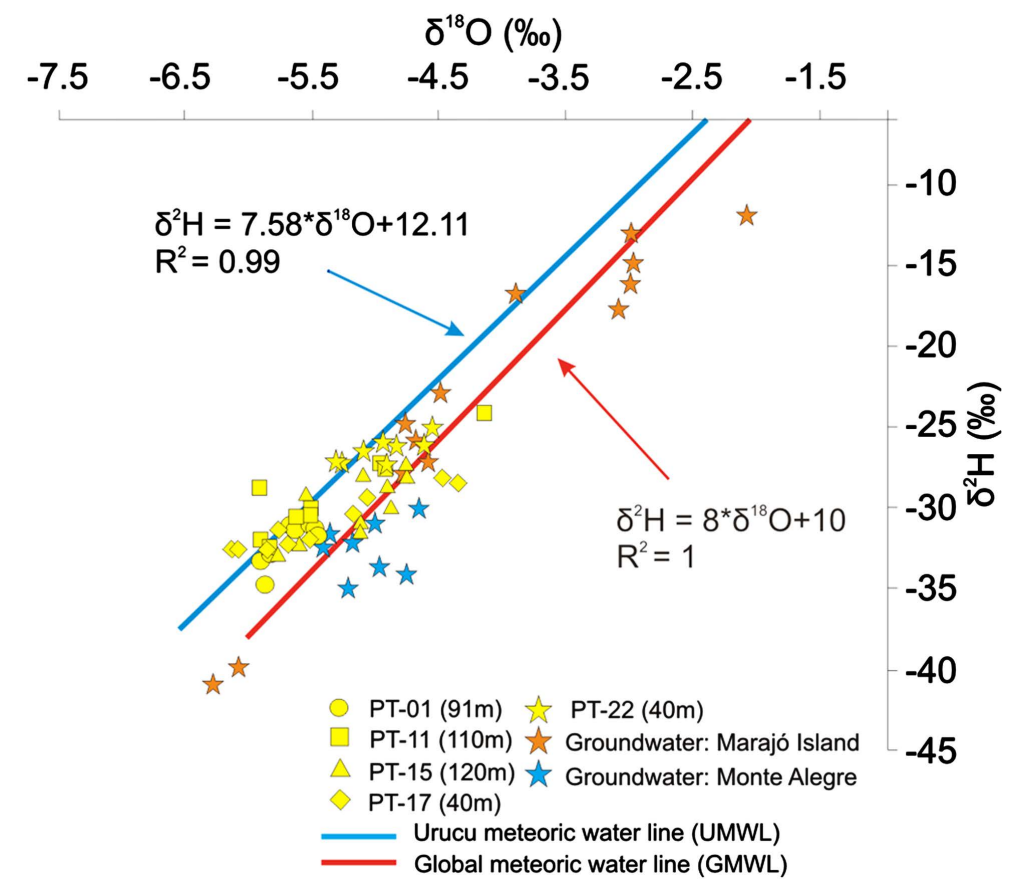

Figure 9. Comparison between groundwater samples collected in Marajó Island [28], in the city of Monte Alegre [39], and Urucu.

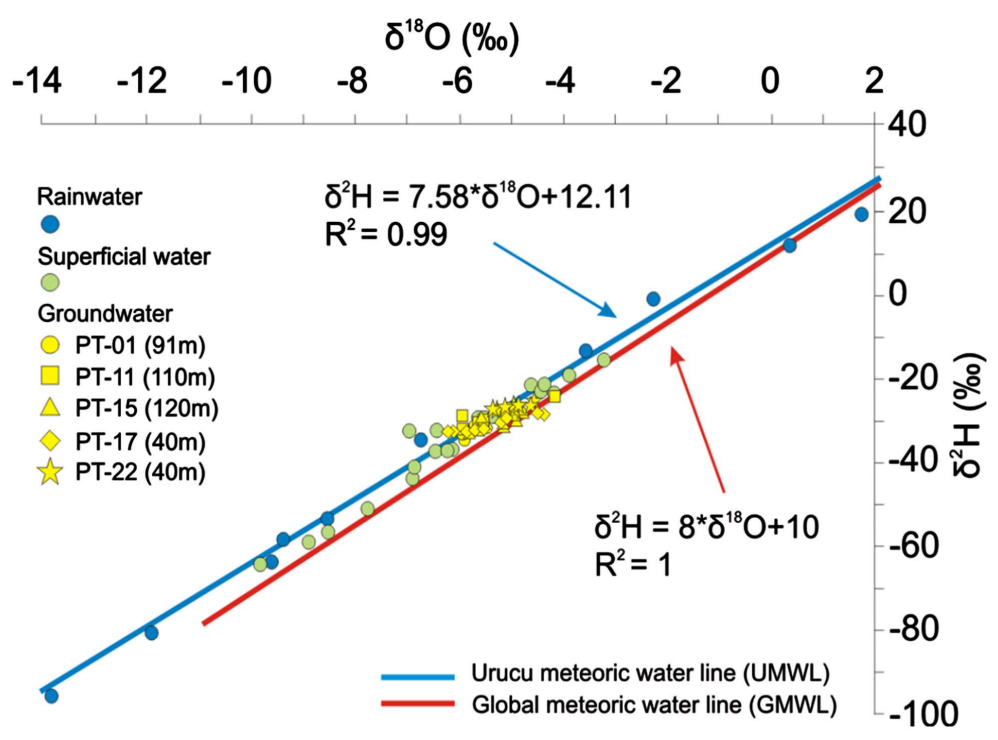

Figure 10. Comparison between rainwater, superficial water and groundwater samples collected in Urucu. 
Comparing rainwater, superficial water, and groundwater samples in the same graphic (Figure 10), the groundwater recharge is originated from local precipitation, explained by the proximity of the samples in the UMWL. The samples are plotted just below the local line, but very close to it, suggesting previous evaporation of these meteoric waters, depleting isotopically, until reach the Içá-Solimões Aquifer System groundwater table. No difference of isotopic signature between shallow and deeper zones of the aquifer were noted, which means that there is only one water source of recharge in the study area. The isotopic signature of groundwater also coincides with the samples collected in the creeks, indicating groundwater discharging contribution in the streams and, therefore, in the Urucu river.

\section{Conclusion}

The isotopic values for rainwater in the study area indicated a proximity to the GMWL and the Meteoric Water Line for Marajó Island, but more negative, suggesting waters slightly lighter, due to the location of the study area being further from the ocean, causing more isotopic fractionation. The superficial waters are typically light waters and have meteoric origin, which confirms rainwater contributions in the creeks. The study also suggests that the groundwater recharge is by direct rainfall infiltration. However, the recharging water might have undergone some primary evaporation in the atmosphere or in the soil zone before reaching the groundwater table in the Içá-Solimões Aquifer System. No difference of isotopic signatures between shallow and deeper zones of the aquifer was observed, suggesting one source of recharge in this aquifer, from rainfall. The similarities of isotopic signatures between groundwater and superficial waters were indicative both waters' contribution in the streams and, therefore, in the Urucu river.

\section{Acknowledgements}

This work was funded by Petrobras and by Federal University of Pará and Federal University of Pernambuco. A special thanks to geologist Kaitlyn Sunshine Beard for the grammar revision and advises.

\section{References}

[1] Clark, I and Fritz, P. (1997) Environmental Isotopes in Hydrogeology. CRC Press, New York, 328 p.

[2] Gat, J.R. (1996) Oxygen and Hydrogen isotopes in the Hydrologic Cycle. Annual Review of Earth and Planetary Sciences, 24, 225-262. http://dx.doi.org/10.1146/annurev.earth.24.1.225

[3] Mook, W.M.E. (2001) Environmental Isotopes in the Hydrological Cycle. Principles and Applications. UNESCO/ IAEA Series.

http://www-naweb.iaea.org/napc/ih/documents/global cycle/Environmental\%20Isotopes\%20in\%20the\%20Hydrologic al\%20Cycle\%20Vol\%201.pdf

[4] Craig, H. (1961) Standard for Reporting Concentration of Deuterium and Oxygen-18 in Natural Waters. Science, 133, 1702-1703. http://dx.doi.org/10.1126/science.133.3465.1702

[5] Kennedy, V.C., Kendall, C., Zellweger, G.W., Wyerman, T.A. and Avanzino, R.J. (1986) Determination of the Components of Stormflow Using Water Chemistry and Environmental Isotopes, Mattole River Basin, California. Journal of Hydrology, 84, 107-140. http://dx.doi.org/10.1016/0022-1694(86)90047-8

[6] Buttle, J.M. (1994) Isotope Hydrograph Separations and Rapid Delivery of Pre-Event Water from Drainage Basins. Progress in Physical Geography, 18, 16-41. http://dx.doi.org/10.1177/030913339401800102

[7] Harris, D.M., McDonnell, J.J. and Rodhe, A. (1995) Hydrograph Separation Using Continuous Open System Isotope Mixing. Water Resources Research, 31, 157-171. http://dx.doi.org/10.1029/94WR01966

[8] Machavaram, M.V., Whittemore, D.O., Conrad, M.E. and Miller, N.L. (2006) Precipitation Induced Stream Flow: An Event Based Chemical and Isotopic Study of a Small Stream in the Great Plains Region of the USA. Journal of Hydrology, 330, 470-480. http://dx.doi.org/10.1016/j.jhydrol.2006.04.004

[9] McKenna, S.A., Ingraham, N.L., Jacobson, R.L. and Cochran, G.F. (1992) A Stable Isotope Study of Bank Storage Mechanisms in the Truckee River Basin. Journal of Hydrology, 134, 203-219. http://dx.doi.org/10.1016/0022-1694(92)90036-U

[10] O’Driscoll, M.A., DeWalle, D.R., McGuire, K.J. and Gburek, W.J. (2005) Seasonal O-18 Variations and Groundwater Recharge for Three Landscape Types in Central Pennsylvania, USA. Journal of Hydrology, 303, 108-124. http://dx.doi.org/10.1016/j.jhydrol.2004.08.020

[11] Lee, K.S. and Kim, Y. (2007) Determining the Seasonality of Groundwater Recharge Using Water Isotopes: A Case 
Study from the Upper North Han River Basin, Korea. Environmental Geology, 52, 853-859. http://dx.doi.org/10.1007/s00254-006-0527-3

[12] Winston, W.E. and Criss, R.E. (2003) Oxygen Isotope and Geochemical Variations in the Missouri River. Environmental Geology, 43, 546-556.

[13] Cartwright, I., Weaver, T.R., Fulton, S., Nichol, C., Reid, M. and Cheng, X. (2004) Hydrogeochemical and Isotopic Constraints on the Origins of Dryland Salinity, Murray Basin, Victoria, Australia. Applied Geochemistry, 19, 12331254. http://dx.doi.org/10.1016/j.apgeochem.2003.12.006

[14] Silveira, C.S. and Silva Junior, G.C. (2002) The Use of Environmental Isotopes in Hydrogeological Studies in Brazil: A Critical Review. Yearbook of the Institute of Geosciences, Vol. 25, UFRJ, Rio de Janeiro.

[15] Gat, J.R., Mazor, E. and Mercado, A. (1968) Potential Applications of Isotopic and Geochemical Techniques to Hydrological Problems of Northeastern Brazil. Report to the Atomic Energy Commission and SUDENE, 28 p.

[16] Ferreira de Melo, F.A., Rebouças, A.C., Gat, J.R. and Mazor, E. (1969) Preliminary Isotope Survey of Water Sources in Northeastern Brazil. SUDENE, Spec. Report 18.

[17] Campos, M.M. (1971) Preliminary Survey of Levels of Tritium in Waters of Northeastern Brazil. Report, IPR, Belo Horizonte, $10 \mathrm{p}$.

[18] Prado, E.B. and Bedmar, A.P. (1976) Contribution of Various Isotopic Techniques to Hydrogeological Study in the Maranhão Basin (Brasil). Hidrologia Journal, April-July, 65-79.

[19] Salati, E., Leal, J.M. and Campos, M.M. (1979) Environmental Isotopes Applied to a Hydrogeological Study of Northeast Brazil. SUDENE, No. 58, Recife, 55 p.

[20] Frischkorn, H., Santiago, M.F. and Serjo, A.N. (1989) Isotope Study of Wells in Crystalline Rock of the Semi-Arid Northeast of Brazil. In: Regional Seminar for Latin America on the Use of Isotope Techniques in Hydrology, Abstracts, OIEA, Mexico City, 73-89.

[21] Santiago, M.F., Frischkorn, H. and Serejo, A.N. (1990) Isotopic Study of the Waters of Cariri. In: 4th Brazilian Groundwater Congress, Brazilian Association of Groundwater, Porto Alegre, 338-342.

[22] Silva, C.M.S.V., Santiago, M.F., Frischkorn, H. and Mendes Filho, J. (1996) Distinction between Alluvial Waters and Deep Waters in the Municipalities of Crato and Juazeiro do Norte-CE. In: 9th Brazilian Groundwater Congress, Brazilian Association of Groundwater, Salvador, CD-ROM São Paulo.

[23] Batista, J.R.X., Santiago, M.M.F., Frischkorn, H., Mendes Filho, J. and Foster, M. (1998) Environmental Isotopes in Groundwater of Picos-PI. In: 10th Brazilian Groundwater Congress, Brazilian Association of Groundwater, São Paulo.

[24] Costa Filho, W.D., Santiago, M.M.F., Costa, W.D. and Mendes Filho, J. (1998) Stable Isotopes and the Quality of Groundwater in the Plain of Recife. In: Brazilian Groundwater Congress, Brazilian Association of Groundwater, São Paulo.

[25] Silva, R.B.G., Kimmelmann, A.A. and Rebouças, A.C. (1985) Hydrochemical and Isotopic Study of Groundwater from the Aquifer Botucatu-Partial Results for the Northern Region of the Paraná Basin. In: 5th Geology Symposium, Atas, São Paulo, Vol. 2, 489-502.

[26] Kimmelmann, A.A., Rebouças, A.C. and Santiago, M.M.F. (1988) ${ }^{14}$ C Dating of the Botucatu Aquifer System in Brazil. In: 13th International Radiocarbon Conference, Abstracts, Iugoslávia, Dubrovinik, 110.

[27] Kimmelmann, A.A., Silva, E., Rebouças, A.C., Santiago, M.M.F. and Silva, R.B.G. (1989) Isotopic Study of the Botucatu Aquifer System in the Brazilian Portion of the Paraná Basin. In: Regional Seminar for Latin America on the Use of Isotope Techniques in Hydrology, Abstracts, OIEA, Ciudad de México, 51-71.

[28] Martins, V.T.S. (2008) Application of Isotopes of Pb, Sr, H and O as Tracers for Recharge and Contamination of Metropolitan Aquifers: An Example from the Upper Tietê Basin (SP). Thesis (PhD in Geology), University of São Paulo, USP, IGc, Institute of Geosciences, 220 .

[29] Matsui, E., Salati, E., Brinkmann, W.L.F. and Friedman, J. (1972) Flows for the Negro and Solimões Rivers through the ${ }^{18} \mathrm{O}$ Concentration. Acta Amazonica, 2, 31-46.

[30] Reis, C.M., Tancredi, A.C.F.N.S., Matsui, E. and Salati, E. (1977) Characterization of Waters in the Region of Marajó through Concentrations of ${ }^{18} \mathrm{O}$ and D. Acta Amazonica, 7, 209-222.

[31] Dall'Olio, A., Salati, E., Azevedo, C.T. and Matsui, E. (1979) Model of Isotopic Fractionation of Water in the Amazon Basin (First Approximation). Acta Amazonica, 9, 675-687.

[32] Salati, E., Dall’Olio, A., Matsui, E. and Gat, J.R. (1979) Recycling of Water in the Amazon Basin: An Isotopic Study. Water Resources Research, 15, 1250-1258. http://dx.doi.org/10.1029/WR015i005p01250

[33] Matsui, E., Salati, E., Ribeiro, M.N.G., Reis, C.M., Tancredi, A.C.S.N.F. and Gat, J.R. (1983) Precipitation in the Central Amazon Basin: The Isotopic Composition of Rain and Atmospheric Moisture at Belém and Manaus. Acta Amazonica, 13, 307-369. 
[34] Gonfiantini, R. (1985) On the Isotopic Composition of Precipitation in Tropical Stations. Acta Amazonica, 15, 121139.

[35] Leopoldo, P.R., Matsui, E., Salati, E., Franken, W. and Ribeiro, M.N.G. (1982) Isotopic Composition of Rainwater and Water from the Soil in the Amazon Forest Bedrock Type, Region of the City of Manaus. Acta Amazonica, 12, 7-13.

[36] Leopoldo, P.R., Matsui, E., Foloni, L.L. and Salati, E. (1984) Variation of the Values of D and ${ }^{18}$ O Sheet in Water during the Evaporation Process. Nuclear Energy and Agriculture, 6, 3-18.

[37] Matsui, E., Azevedo, C.T. and Salati, E. (1980) Distribution of Deuterium in Surface and Ground Waters in Brazil. Nuclear Energy and Agriculture, 2, 149-165.

[38] Mortatti, J., Martinelli, L.A., Matsui, E., Victoria, R.L. and Richey, J.E. (1987) Isotopic Variation of Oxygen in the Water of River Solimões/Amazon and Its Main Tributaries. Energia Nuclear E Agricultura, 8, 14-23.

[39] Lopes, E.C.S. (2005) Hydrogeochemical and Geophysical Studies of the Braquidobra Region of Monte Alegre/PA. Dissertation (MSc in Geology), Federal University of Pará, Centre of Geosciences, School of Postgraduate Geology and Geochemistry, Belém, 75 p.

[40] Petrobras. (2010) Urucu Oil Province. http://www2.petrobras.com.br/minisite/urucu/urucu.html

[41] Galvão, P.H.F. (2011) Hydrogeological Characterization of the Aquifers of Solimões Formation in the Geologist Pedro de Moura Operational Base, Urucu Oil Province (AM). Dissertation (MSc in Geology), Federal University of Pernambuco, CTG, Graduate Program in Geosciences, Recife, 148 p.

[42] Caputo, M.V. (1984) Stratigraphy, Tectonics, Paleoclimatology and Paleogeography of Northern Basins of Brasil. Ph.D. Thesis, University of California, Santa Barbara, 586 p.

[43] Eiras, J.F., Becker, C.R., Souza, E.M., Gonzaga, F.G., Silva, J.G.F. and Daniel, L.M.F. (1994) Solimões Basin. Petrobras Bulletin of Geosciences, 8, 17-45.

[44] Caputo, M.V. and Silva, O.B. (1991) Sedimentation and Tectonics in the Solimões Basin. In: Raja Gabaglia, G.P. and Milani, E.J., Eds., Origin and Evolution of Sedimentary Basins, Petrobras, Rio de Janeiro, 169-193.

[45] Caputo, M.V., Rodrigues, R. and Vasconcelos, D.N.N. (1971) Lithostratigraphy of the Amazon Basin. Internal Report, Petrobras, Belém.

[46] Caputo, M.V., Rodrigues, R. and Vasconcelos, D.N.N. (1972) Stratigraphic Nomenclature of the Amazon Basin: History and Update. In: 26th Brazilian Congress of Geology, Brazilian Society of Geology, Belém, Vol. 3, 35-46.

[47] Cruz, N.M.C. (1987) Quitinozoarious from Solimões Basin, Brazil. Internal Report, Belém Covenant CPRM/Petrobras.

[48] Nogueira, A.C.R., Arai, M., Horbe, A.M., Silveira, R.R. and Silva, J.S. (2003) The Marine Influence in Deposits of the Solimões Formation in the Region of Coari (AM): Registration of the Miocene Transgression in the Western Amazon. In: 8th Symposium on Geology of the Amazon, Abstracts, Brazilian Society of Geology, Manaus.

[49] Galvão, P.H.F., Demétrio, J.G.A., Souza, E.L., Pinheiro, C.S.S. and Baessa, M.P.M. (2012) Hydrogeological and Geometric Characterization of the Iça and Solimões Formations in Urucu Area, Amazonas State. Brazilian Journal of Geology, 42, 142-153.

[50] IAEA/WHO (2004) Global Network of Isotopes in Precipitation. The GNIP Database. http://isohis.iaea.org

[51] Leng, M.J. (2006) Isotopes in Palaeoenvironmental Research. Springer Verlag, Berlin, 307 p.

[52] Vuille, M. and Werner, M. (2005) Stable Isotopes in Precipitation Recording South American Summer Monsoon and ENSO Variability: Observations and Model Results. Climate Dynamics, 25, 401-413. http://dx.doi.org/10.1007/s00382-005-0049-9

[53] Mazor, E. (1991) Applied Chemical and Isotopic Groundwater Hydrology. Open University Press, Suffolk, 274 p. 
Scientific Research Publishing (SCIRP) is one of the largest Open Access journal publishers. It is currently publishing more than 200 open access, online, peer-reviewed journals covering a wide range of academic disciplines. SCIRP serves the worldwide academic communities and contributes to the progress and application of science with its publication.

Other selected journals from SCIRP are listed as below. Submit your manuscript to us via either submit@scirp.org or Online Submission Portal.
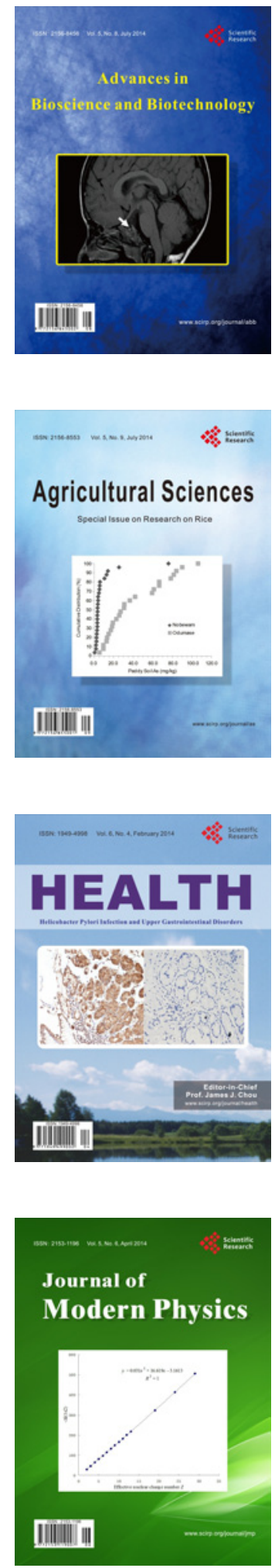
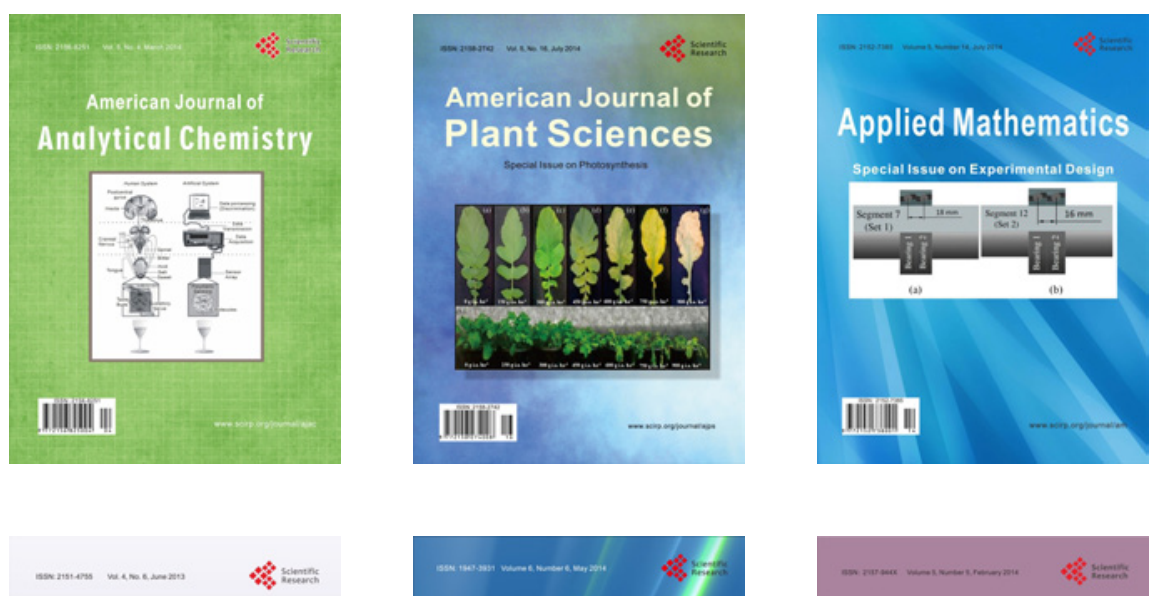

Creative Education
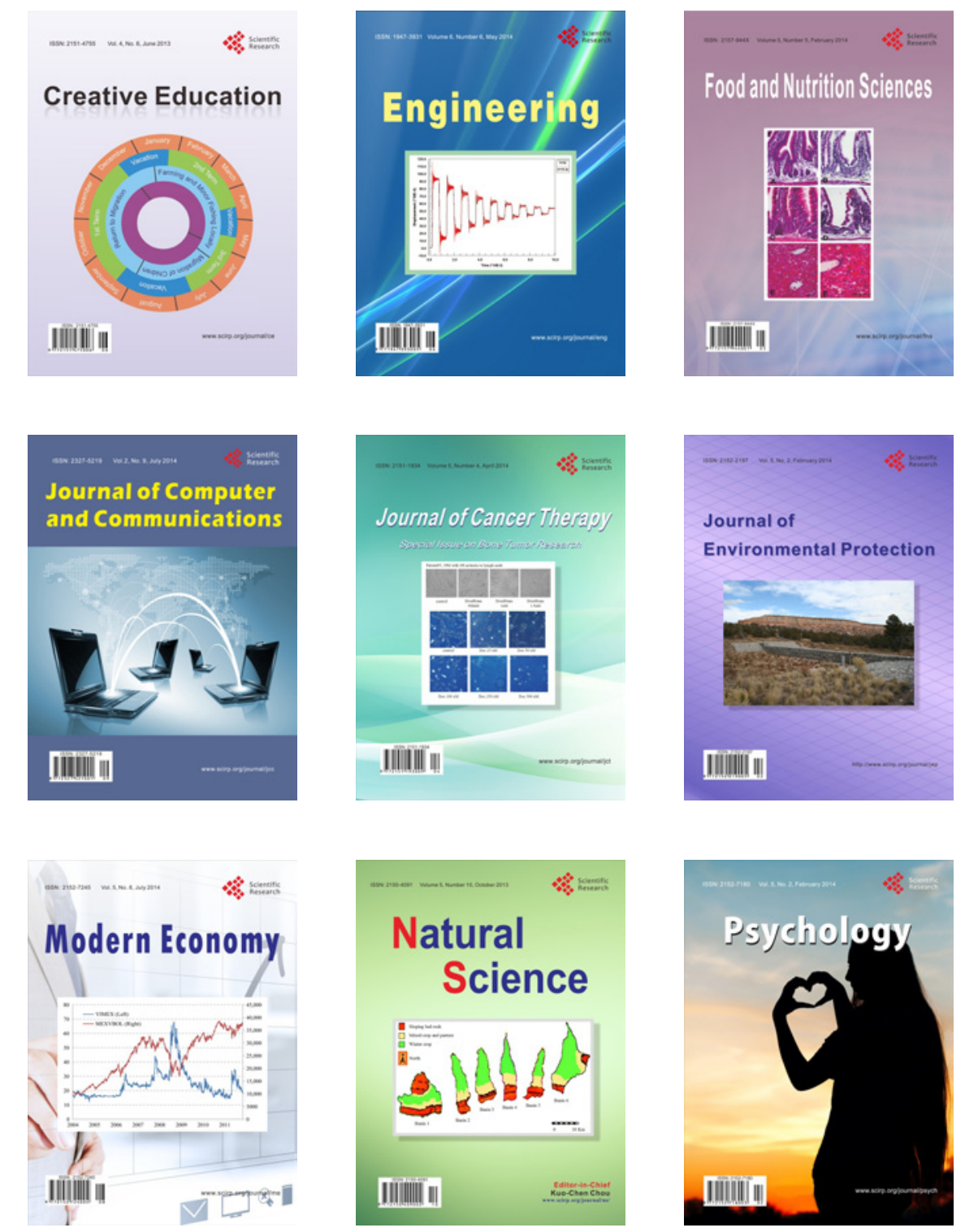